Supplement of Atmos. Chem. Phys., 17, 6323-6339, 2017

http://www.atmos-chem-phys.net/17/6323/2017/

doi:10.5194/acp-17-6323-2017-supplement

(C) Author(s) 2017. CC Attribution 3.0 License.

(c) (i)

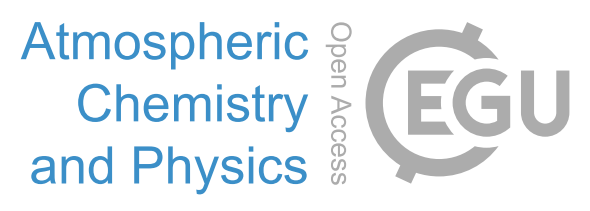

Supplement of

\title{
Heterogeneous uptake of ammonia and dimethylamine into sulfuric and oxalic acid particles
}

Meike Sauerwein and Chak Keung Chan

Correspondence to: Chak Keung Chan (chak.k.chan@cityu.edu.hk)

The copyright of individual parts of the supplement might differ from the CC-BY 3.0 licence. 


\section{Supplementary Figures}

Figure S1: Experimental setup of simultaneous absorption of dimethylamine and ammonia in sulfuric acid and oxalic acid particles. The experimental procedure includes RH conditioning, Gas generation, Flow cell reaction, Particle analysis with the Ion Chromatograph, and Phase state and morphology observation with a Microscope Raman. Abbreviations: $\mathrm{HP} \mathrm{N}_{2}$, high purity nitrogen gas, RH, relative humidity; DMA,

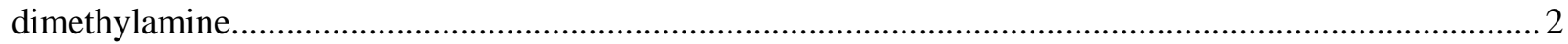

Figure S2: Morphological changes during the uptake of $1.0 \mathrm{ppm} \mathrm{DMA}$ and $1.9 \mathrm{ppm} \mathrm{NH}_{3}$ into oxalic acid particles at $70 \% \mathrm{RH}$. 3 


\section{Methods}

\section{Experimental setup}

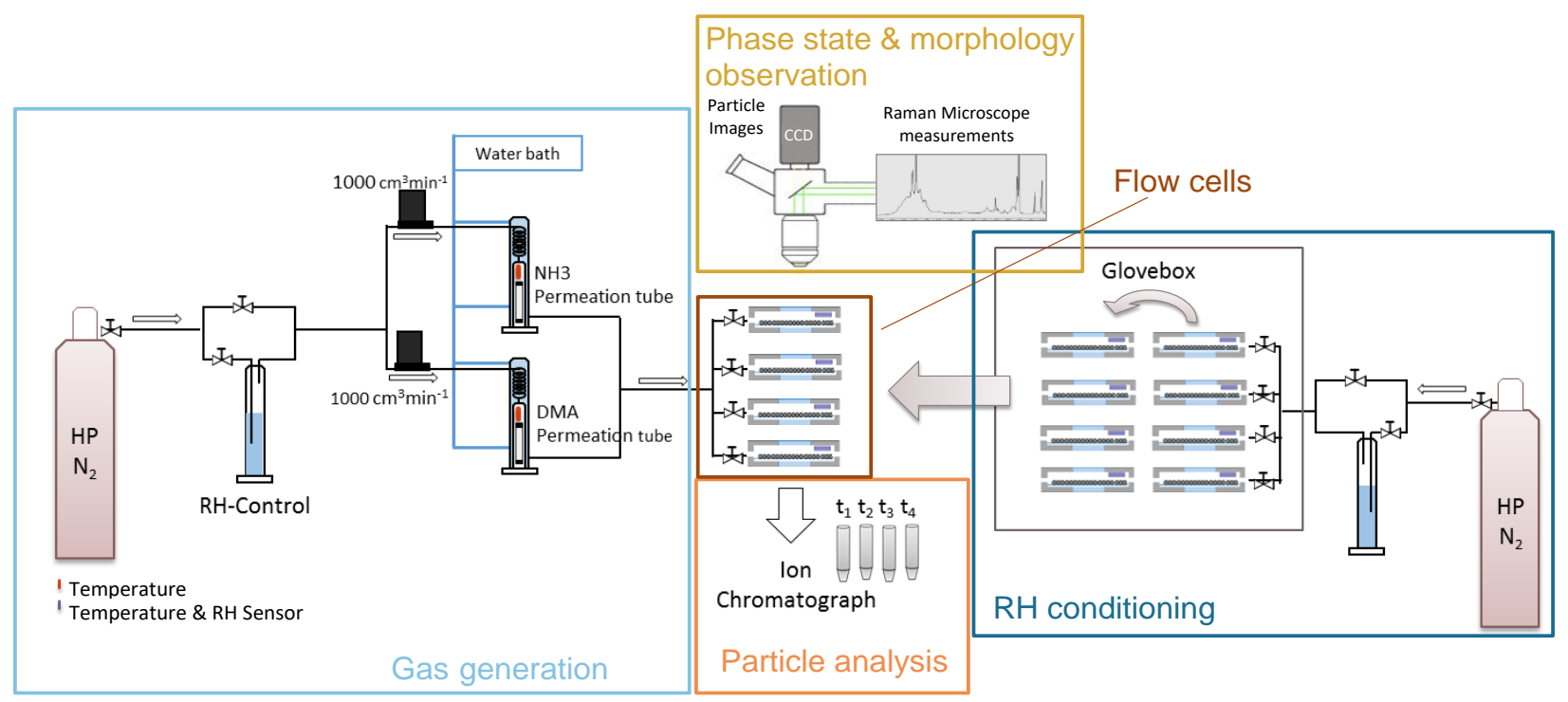

Figure S1: Experimental setup of simultaneous absorption of dimethylamine and ammonia in sulfuric acid and oxalic acid particles. The experimental procedure includes RH conditioning, Gas generation, Flow cell reaction, Particle analysis with the Ion Chromatograph, and Phase state and morphology observation with a Microscope Raman. Abbreviations: HP $\mathrm{N}_{2}$, high purity nitrogen gas, $\mathrm{RH}$, relative humidity; DMA, dimethylamine.

\section{Gas generation system}

The general setup including the gas generation system was tested using an ion-molecule reaction mass spectrometry (IMR-MS, AirSense, V\&F Analyse-und Messtechnik GmbH).

\section{Temperature sensitivity}

Temperature sensitivity of the gas generation system was tested with permeation tubes for $\mathrm{NH}_{3}$ (permeation rates: $\sim 2700 \mathrm{ng} / \mathrm{min}$ at $293 \mathrm{~K}$ ) and for the DMA (permeation rates: $\sim 400 \mathrm{ng} / \mathrm{min}$ at $293 \mathrm{~K}$ ). Temperatures inside permeation tube holders were increased in small steps between 19.0 and $21.0 \mathrm{~K}$. The temperature raise yielded a stronger increase in $\mathrm{NH}_{3}$ than in DMA concentrations, causing a systematic decrease in DMA/ $/ \mathrm{NH}_{3}$ ratio of $4 \% / \mathrm{K}$. DMA concentrations generated from smaller permeation tubes (permeation rates $\sim 550 \mathrm{ng} / \mathrm{min}$ at $293 \mathrm{~K}$, flowrate: $2000 \mathrm{~cm}^{3} / \mathrm{min}$ ) were near the detection limit of the IMR-MS. Permeation rate changes with temperature were estimated based on

$\log \mathrm{P}_{1}=\log \mathrm{P}_{0}+\alpha\left(\mathrm{T}_{1}-\mathrm{T}_{0}\right)$

where $\mathrm{P}_{0}=$ Rate at temp $\mathrm{T}_{0}\left({ }^{\circ} \mathrm{C}\right), \mathrm{P}_{1}=\mathrm{New}$ rate at temp $\mathrm{T}_{1}\left({ }^{\circ} \mathrm{C}\right)$, and $\alpha=$ the temperature coefficient $(0.034)$, and would yield an approximate change in DMA concentrations by $3 \% / \mathrm{K}$. In the final experiment temperature could be controlled to $\pm 0.2 \mathrm{~K}$, hence $\mathrm{DMA} / \mathrm{NH}_{3}$ ratio changes due to temperature fluctuations were $<1 \%$. 
These uncertainties in the $\mathrm{DMA} / \mathrm{NH}_{3}$ gas phase ratios due to temperature fluctuations were significantly smaller than uncertainties related to gravimetric measurements. The overall uncertainty of $\mathrm{DMA} / \mathrm{NH}_{3}$ gas phase ratios was estimated to be 5-8 \% as listed in Table 1 of the manuscript.

\section{Equilibration time}

As $\mathrm{NH}_{3}$ and DMA are both very "sticky" gases (Robacker and Bartelt 1996, Hansen et al. 2013, Dawson et al. 2014), they are prone to adsorb to instrumental surfaces. Yet, the stickiness varies among different amines and ammonia (Namieśnik et al. 2003, Dawson et al. 2014). Test measurements using IMR-MS connected to the gas generation system showed that the reestablishment of stable gas concentrations at the inlet of the flow cell after the system underwent a cleaning process took up to 4 hours for $\mathrm{NH}_{3}$ and up to 8 hours for DMA. A much shorter recovery time of $<1$ hour for both gases, was observed if only the gas supply was temporarily interrupted (e.g. for weighing permeation tubes, and/or changing the $\mathrm{N}_{2}$ cylinder).

Since a drop in the concentration of one or both gases (e.g. due to wall losses) would result in a change of DMA/ $\mathrm{NH}_{3}$ ratio, we allowed $2 \mathrm{~h}$ equilibration time when the gas supply was interrupted and about 12 hours for reconditioning after the setup was cleaned. Since flow cells were likewise conditioned with DMA and $\mathrm{NH}_{3}$ gas, we equilibrated the sulfuric acid or oxalic acid particles to the respective $\mathrm{RH}$ of $10 \%$ or $50 \%$ in separate clean cells.

\section{Results and discussion}

\section{Section 3. Uptake into oxalic acid particles}

ox0.5 $70 \%$

\begin{tabular}{|c|c|c|c|c|c|c|}
\hline $\mathbf{t}=1 \mathrm{~min}$ & $\mathbf{t}=6 \mathrm{~min}$ & $\mathbf{t}=10 \mathrm{~min}$ & $\mathbf{t}=19 \mathrm{~min}$ & $\mathbf{t}=32 \mathrm{~min}$ & $\mathbf{t}=75 \mathrm{~min}$ & $\mathbf{t}=205 \mathrm{~min}$ \\
\hline & & & & & & \\
& & & & & & \\
& & & & & & \\
& & & & & & \\
\hline
\end{tabular}

Figure S2: Morphological changes during the uptake of $1.0 \mathrm{ppm}$ DMA and $1.9 \mathrm{ppm} \mathrm{NH} \mathrm{N}_{3}$ into oxalic acid particles at $70 \% \mathrm{RH}$.

\section{References}

Dawson, M.L., Varner, M.E., Perraud ,V., Ezell, M.J., Wilson J, Zelenyuk A, Gerber R.B., FinlaysonPitts B.J.: Amine-Amine Exchange in Aminium-Methanesulfonate, Aerosols. J. Phys. Chem. C, 118 (50), 29431-29440, 2014. 
Hansen, M.J., Adamsen, A.P.S., Feilberg, A.: Recovery of odorants from an olfactometer measured by proton-transfer-reaction mass spectrometry. Sensors, 13(6), 7860-7871, 2013.

Namieśnik J., Jastrzębska, A., Zygmunt, B.: Determination of volatile aliphatic amines in air by solidphase microextraction coupled with gas chromatography with flame ionization detection. J. Phys. Chem. A, 1016(1), 1-9, 2003.

Robacker D.C., Bartelt R.J.: Solid-Phase Microextraction Analysis of Static-Air Emissions of Ammonia, Methylamine, and Putrescine from a Lure for the Mexican Fruit Fly (Anastrephaludens ), J. Agric. Food Chem., 44(11), 3554-3559, 1996. 